\title{
EFECTOS DE UNA CAMPAÑA EDUCATIVA SOBRE FRIJOLES EN UN GRUPO DE MUJERES1
}

\section{EFFECTS OF AN EDUCATIONAL CAMPAIGN ABOUT BEANS ON A GROUP OF WOMEN1}

\author{
Marcela Dumani², Paola Páez ${ }^{3}$
}

\section{RESUMEN}

Efectos de una Campaña educativa sobre frijoles en un grupo de mujeres. Se presentan los efectos de una Campaña educativa sobre frijoles en un grupo de mujeres de clase media, madres de escolares; que constituyeron el grupo objetivo de la mencionada Campaña. Estas madres presentaban la particularidad de que sus hijos e hijas escolares, también habían sido expuestos (as) a la Campaña. Los escolares constituían el "grupo interactivo", ya que por su estrecho contacto con las madres, podían ser un medio de comunicación y de refuerzo de los mensajes dirigidos a ellas. Los efectos se valoraron con respecto a los conocimientos, actitudes y prácticas de las madres en relación con los frijoles; confrontando lo encontrado con los "indicadores de éxito" planteados para la Campaña. Además, para algunas de las prácticas, fue posible establecer comparaciones cuantitativas con los datos obtenidos en el diagnóstico inicial. Los resultados revelaron efectos positivos de la Campaña en las mujeres. Se comprobó un incremento importante en la frecuencia del consumo de frijoles, una actitud positiva ante los mismos y un mejoramiento de las prácticas de preparación, consumo y conservación del producto.

Palabras claves: frijoles, Campaña educativa, indicadores de éxito, evaluación

\begin{abstract}
Effects of an educational Campaign about beans on a group of women. The effects of an educational Campaign about beans on a group of middle-class mothers with school children who were the target group of this study, are presented in this article. The particular characteristic of this group of women was that their children had also been exposed to the Campaign. The students were the "interactive group", because their close contact with their mothers, allowed them to act as a communication channel to reinforce the messages addressed to them. The effects are evaluated as knowledge, attitudes, and practices of the mothers with regards to beans, comparing findings with "success indicators" proposed for the Campaign. With the data obtained in the initial assessment it was also possible to make quantitative comparisons of some of the practices. Results revealed that the Campaign had positive effects on women. An important increase in bean consumption by families, a positive attitude about beans, and improvements in their preparation, consumption, and preservation were observed after the Campaign.
\end{abstract}

Key words: beans, educational Campaign, success indicators, final evaluation.
1 Recibido para publicación el 30 de junio del 2004. Este artículo se deriva de la investigación desarrollada en el Proyecto Campaña Educativa para Promover el Consumo de Frijoles, de la Escuela de Nutrición de la UCR, inscrito dentro del proyecto macro "Mejoramiento de la Digestibilidad del Frijol", CITA-UCR, bajo el auspicio del Programa Bean/Cowpea CRSP; USAID Grant DAN-G-SS-86-0008-88.

2 Escuela de Nutrición, Universidad de Costa Rica. E-mail: mdumani@racsa.co.cr

3 Escuela de Nutrición, Universidad de Costa Rica.

\footnotetext{
1 Received for publication on June 30, 2004. This article is the result from the investigation carried out in the Project "Educational Campaign to Increase Bean Consumption", from the University of Costa Rica's Nutrition School, which is part of the macro-project "Improving Digestibility of Beans", CITA, UCR, sponsored by the Bean/Cowpea CRSP Program; USAID Grant DAN-G-SS-86-0008-88.

2 University of Costa Rica, School of Nutrition. E-mail: mdumani@racsa.co.cr

2 University of Costa Rica, School of Nutrition.
} 


\section{INTRODUCCIÓN}

Los cambios socioeconómicos ocurridos en los últimos tiempos han contribuido a una modificación de los hábitos alimentarios de la población costarricense (INCAP/ICNN/Ministerio de Salubridad Pública de Costa Rica 1966, Ministerio de Salud 1986, Ministerio de Salud y Dirección General de Estadísticas y Censos 1991; Ministerio de Salud 1996). La disponibilidad de alimentos se ha visto afectada por la disminución de la biodiversidad y por una oferta muy abundante de productos procesados, no necesariamente originarios del país y de su cultura alimentaria. Por otra parte, el estilo de vida sedentario es cada vez más frecuente, debido al urbanismo y a la creciente utilización de la tecnología.

En consecuencia, se han generado algunos hábitos alimentarios inadecuados, los que asociados con el sedentarismo favorecen la presencia de enfermedades cardiovasculares, obesidad, diabetes, anemia y algunos tipos de cáncer. En nuestro país, por ejemplo, fue evidente la disminución en el consumo de frijoles observada entre 1966 y 1996, específicamente en la población urbana, pasando de 48 a 28,1 gramos por persona por día según los resultados de las encuestas nacionales de nutrición correspondientes a esos años. (INCAP/ICNND/ Ministerio de Salubridad Pública de Costa Rica 1969; Ministerio de Salud 1996).

Debe resaltarse que los frijoles por su contenido nutritivo y de otros elementos, son considerados un alimento funcional que contribuye a la prevención de enfermedades crónicas y cáncer, muy frecuentes en la población costarricense (Rodríguez y Fernández 2003).

Por consiguiente, es necesario definir estrategias para lograr que la población reasuma sus hábitos alimentarios positivos, tales como el consumo de frijoles en mayores cantidades. Una alternativa estratégica para lograr ese propósito es la realización de una Campaña educativa que promueva el consumo de este alimento.

El campo de acción de la educación nutricional es toda la comunidad y sus acciones pueden ejercerse en los distintos niveles de prevención. No obstante, dado que ni las características personales, ni las situaciones son homogéneas, se suelen dirigir los esfuerzos a ámbitos y grupos concretos, teniéndose en cuenta la edad, el género, el rol familiar y otras características (ENCA 1997-1998, FAO 1996).

Las madres de familia constituyen un importante grupo objetivo para desarrollar acciones educativas en nutrición. Escobar, citado por Fernández et al. (2000), indica que el buen estado nutricional de la familia

\section{INTRODUCTION}

Socioeconomic changes experienced during the last years have contributed to modify alimentary habits of the Costa Rican population (INCAP/ICNN/ Ministerio de Salubridad Pública de Costa Rica, 1966; Ministerio de Salud 1986; Ministerio de Salud y Dirección General de Estadísticas y Censos 1991; Ministerio de Salud, 1996). Food availability has been affected by a decreasing biodiversity on the one side, and on the other, due to an abundant offering of processed products that are not necessarily part of the country's alimentary culture. Moreover, the urbanization process and a greater use of technology, have led to an increasingly sedentary lifestyle.

These changes constitute risk factors for cardiovascular diseases, obesity, diabetes, anemia, and some types of cancer. For instance, a great reduction in bean consumption has been observed in Costa Rica between 1966 and 1996, specifically among urban populations, where it went from 48 grams per person per day $(\mathrm{g} / \mathrm{p} /$ day) to $28.1 \mathrm{~g} / \mathrm{p} /$ day, according to results from national nutrition surveys corresponding to that period of time (INCAP/ICNND/Ministerio de Salubridad Pública de Costa Rica 1969; Ministerio de Salud 1996).

Due to their nutritional content and other elements, beans are considered a functional food that helps prevent chronic diseases and cancer, which are prevailing among the Costa Rican population (Rodríguez and Fernández 2003).

Therefore, strategies should be defined to restore healthful alimentary habits, such as consuming greater amounts of beans. An alternative strategy to achieve this purpose is carrying out an educational Campaign to increase bean consumption.

Nutritional education must be a concern to the whole community, where actions may be implemented at different prevention levels. However, given that individual characteristics and situations are not the same everywhere, efforts must be aimed at concrete contexts and groups, taking into account age, gender, family role, and other characteristics (ENCA 19971998, FAO 1996).

Mothers are an important target group for nutritional education. Escobar, quoted by Fernández et al. (2000), indicates that a family's good nutritional condition depends greatly on what the mother knows and puts into practice with regards to nutrition. Women are the ones who predominantly select and prepare 
depende en gran medida de lo que la madre sabe y practica en relación con la alimentación. Es la mujer la que aún predominantemente selecciona y prepara los alimentos y hereda los conocimientos culinarios, influyendo las costumbres alimentarias (De la Riva 1998).

En la Campaña educativa para incrementar el consumo de frijoles, el grupo objetivo estuvo constituido por madres de clase media con escolares, de Sabanilla de Montes de Oca. Los conocimientos, actitudes y prácticas (CAPS) con respecto a los frijoles, ya habían sido obtenidos en una muestra de esas madres, en el diagnóstico inicial (Campos et al. 1999; Rodríguez y Rodríguez 2003; Murillo y Rodríguez 2004a; Rodríguez y Murillo 2004). Al planificar la Campaña con fundamento en ese diagnóstico, se plantearon los indicadores de éxito que se esperaba obtener como resultado de la misma. Este estudio presenta una valoración de esos indicadores de éxito un año después de haberse iniciado la etapa de ejecución de la Campaña educativa ${ }^{4}$.

Las actividades interactivas y de comunicación masiva que se desarrollaron durante la ejecución de la Campaña se describen en Rodríguez y Rodríguez (2004). Este trabajo tuvo como objetivo determinar los efectos de la Campaña educativa ${ }^{4}$ sobre los conocimientos, las actitudes y las prácticas de las madres, con respecto a los frijoles.

\section{MATERIALES Y MÉTODOS}

\section{a) Población}

El estudio se llevó a cabo, con un grupo de madres de escolares, de clase media de la comunidad de Sabanilla de Montes de Oca situada a 6 kilómetros de San José, capital de Costa Rica. Dichas madres formaban parte del grupo objetivo de la "Campaña Educativa para Incrementar el Consumo de Frijoles". La particularidad de este grupo de madres, es que estuvieron expuestas a los materiales y a las actividades de la Campaña educativa. Además, por ser madres de niños y niñas de tercero y cuarto grado de las escuelas José Figueres Ferrer y del Centro Educativo Campestre (ambas incluidas en el estudio) contaron con el refuerzo de los escolares que constituyeron el "grupo interactivo" de la Campaña. Con ellos se desarrollaron diversas actividades sobre frijoles y a sus madres les fueron enviados los panfletos, el recetario y otros materiales de la Campaña (Dumani y López 2004).

4 La ejecución de la Campaña se inicio a mediados de setiembre y concluyó a mediados de diciembre del año 2000. Se reinició de nuevo en febrero y terminó en abril del 2001. food, and the ones that pass on culinary knowledge to the next generations, thus influencing alimentary habits (De la Riva, 1998).

The target group for the educational Campaign to increase bean consumption was a group of middleclass mothers with school children from Sabanilla de Montes de Oca. Information about knowledge, attitudes, and practices with regards to beans had already been obtained in the initial assessment from a sample of those women (Campos et al. 1999; Rodríguez and Rodríguez 2003; Murillo and Rodríguez 2004a; Rodríguez and Murillo 2004). The Campaign was planned based on this assessment, including success indicators for expected results. The success indicators to be achieved as a result of the Campaign were set forth ${ }^{4}$.

Interactive and mass communication activities carried out during implementation of the Campaign are described in Rodríguez and Rodríguez (2004). The objective of this work was to determine the effects of the educational Campaign on mothers' knowledge, attitudes and practices with regards to beans

\section{MATERIALS AND METHODS}

\section{a) Population}

This study was carried out with a group of middleclass mothers with school children from the community of Sabanilla de Montes de Oca, located 6 kilometers away from San José, the capital city of Costa Rica. These mothers were the target group of the "Educational Campaign to Increase Bean Consumption". The particular characteristic of this group of mothers was that they were exposed to the materials and activities of the educational Campaign. In addition, since their children were in third and fourth grades at the José Figueres Ferrer School and the Centro Educativo Campestre (that were part of the study), they received reinforcement from their children, who were the "interactive group" of the Campaign. Several bean-related activities were carried out with them, and their mothers received the brochures, the recipe book and other materials from the Campaign (Dumani and López 2004).

This work was carried out with a sub-sample from the study about bean consumption in families (Rodríguez and Páez 2004). Said study covered a

\footnotetext{
4 Campaign implementation started in the middle of September and ended in the middle of December of the year 2000. It started again in February, and ended in April, 2001.
} 
Esta evaluación se realizó en una submuestra del estudio sobre consumo de frijoles en las familias (Rodríguez y Páez 2004). El estudio sobre consumo de frijoles abarcó una muestra al azar de 60 familias con niños escolares. De esa muestra, se captaron para esta evaluación únicamente 23 madres, que presentaron la condición preestablecida de haber tenido hijos o hijas en tercero o cuarto grados de las escuelas ya mencionadas, cuando se ejecutaron las actividades interactivas del plan de las escuelas. De la submuestra de 23 madres, fue necesario eliminar tres casos: uno porque la información estaba incompleta y dos porque no habían tenido conocimiento sobre la Campaña. Por lo tanto, la información que se presenta a continuación corresponde a un grupo de 20 madres. Aunque el número es reducido, el aporte de ellas es muy importante como parte del proceso.

\section{b) Recolección de datos}

Los datos fueron recogidos a finales del 2001, un año después de haber iniciado la etapa de ejecución de la Campaña en la comunidad. La información se recolectó mediante una entrevista estructurada sobre los conocimientos, las actitudes y las prácticas (CAPs) de las madres en relación con los frijoles.

Los datos fueron recolectados utilizando un cuestionario previamente validado, por tres nutricionistas (miembros del equipo de trabajo), una asistente (estudiante de nutrición avanzada) y una líder de la comunidad, la cual fue capacitada en forma individual.

\section{RESULTADOS Y DISCUSIÓN}

Catorce de las 20 madres eran amas de casa y por lo tanto, no tenían un trabajo remunerado. Cinco de las seis restantes desempeñaban puestos de secretaria, estilista y dependiente, categorías que tienen una baja remuneración en la escala salarial. Solamente una madre indicó que era comerciante.

\section{Difusión de la Campaña educativa}

Antes de analizar los efectos de la Campaña educativa sobre las madres se consideró necesario describir su exposición a la Campaña.

\section{a. Contacto de las madres con la campaña}

El Cuadro 1 revela la importancia de la escuela y del trabajo desarrollado con los escolares (grupo interactivo), random sample of 60 families with school children. Out of this sample, only 23 mothers were covered by the present study, because they met the pre-requirement of having had children in third or fourth grades in the mentioned schools while the interactive activities of the plan for schools were implemented. Three cases were excluded from the sub-sample of 23 mothers: one because the information provided was incomplete, and two because they had not received information about the Campaign. Therefore, the information presented below covers only 20 mothers. Although the sample is small, this research made an important contribution to the process as a whole.

\section{b) Data collection}

Data were collected at the end of 2001, one year after the Campaign implementation phase had been launched in the community. Information was gathered through a structured interview about the mother's knowledge, attitudes and practices (KAPs) with regards to beans.

Data were collected using a previously validated questionnaire applied by three nutritionists (members from the work team), one assistant (an advanced nutrition student) and a community leader who was individually trained.

\section{RESULTS AND DISCUSSION}

Fourteen of the 20 mothers worked in the house and therefore they did not have a remunerated job. Five of the other 6 worked as secretaries, stylists, and sales clerks, classified as low-wage jobs according to the salary scale. Only one mother said that she was a merchant.

\section{Dissemination of information about the educational Campaign}

Before analyzing the effects of the educational Campaign on mothers, it is necessary to describe their exposure to it.

\section{a. Contact of mothers with the Campaign}

The important role of the schools and the work carried out with the school children (interactive group) as a means to disseminate information is presented in Table 1. Without the schools' participation, none of the other means used would have succeeded in achieving 
Cuadro 1. Contacto de las madres con la Campaña según medio. Campaña Educativa para incrementar el consumo de frijoles. Sabanilla de Montes de Oca, Costa Rica, 2001.

\begin{tabular}{lc}
\hline \multicolumn{1}{c}{ Medio } & No. de madres ${ }^{*}$ \\
\hline Escuela o escolares & 20 \\
Afiches & 7 \\
Radio, TV y periódicos & 4 \\
Supermercado & 2 \\
Amigas y pastoral de la iglesia & 2 \\
Universidad de Costa Rica & 2 \\
Feria & 1 \\
Total & $\underline{38}$ \\
\hline
\end{tabular}

*Los datos no son excluyentes ya que una misma madre puede dar más de una respuesta.

como medio de difusión de la información. Otros medios utilizados, aunque importantes como parte de la Campaña, por sí solos no habrían permitido el grado de difusión alcanzado, o se habría requerido de una gran inversión para lograrlo.

El segundo lugar en difusión de la campaña, lo ocuparon los afiches, ubicados en sitios concurridos de la comunidad, incluyendo los supermercados. Los sitios seleccionados para su exposición fueron correctamente elegidos por las investigadoras, de acuerdo con la información del diagnóstico inicial (Campos et al. 1999). Es probable, además, que el diseño del afiche lograra captar la atención de las personas. El dibujo del personaje del frijol utilizado también en el afiche, fue muy bien aceptado por las madres, al valorar los panfletos (Dumani y López 2004).

Los medios de comunicación masiva también fueron importantes en los esfuerzos de difusión. El Cuadro 1 revela que es importante el abordaje por varios canales que se refuercen unos a otros y permitan llegar a más sectores de la población. La utilización de diferentes medios y canales es recomendada por diversos autores (FAO 1996, Alcalay 1983).

\section{b. Exposición de las madres a los materiales de la Campaña}

Para la Campaña fueron elaborados dos panfletos y un recetario que sirvieron de apoyo educativo. Estos fueron enviados a todas las madres de los niños y niñas de tercero y cuarto grados de las escuelas señaladas anteriormente, en total 160 mujeres. Sin embargo, en las 20 madres estudiadas, algunos materiales no llegaron a su destino. El Cuadro 2 resume esta información.
Table 1. Contact of mothers with the Campaign, by means used. Educational Campaign to increase bean consumption. Sabanilla de Montes de Oca, Costa Rica, 2001.

\begin{tabular}{lc}
\hline \multicolumn{1}{c}{ Means } & $\mathbf{N}^{\circ}$ of mothers* \\
\hline School or school children & 20 \\
Posters & 7 \\
Radio, TV and newspapers & 4 \\
Supermarket & 2 \\
Friends and Catholic church group & 2 \\
University of Costa Rica & 2 \\
Fair & 1 \\
Total & $\underline{38}$ \\
\hline
\end{tabular}

* Data are not mutually exclusive because one mother may give more than one answer.

such dissemination, and a great financial investment would have been required.

Posters occupied the second place in terms of dissemination of information for the Campaign. They were displayed in highly frequented places throughout the community, including supermarkets. Researchers chose strategic places for displays, based on the information obtained during the initial assessment (Campos et al. 1999). Moreover, it is likely that the poster design caught people's attention. The drawing of the bean character also used in the posters, was widely accepted by the mothers when they assessed the brochures (Dumani and López 2004).

Mass media also played an important role in the information dissemination efforts. As shown in Table 1, it is important to use several communication channels reinforcing each other, thus reaching more people. In fact, use of different mass media and communication channels is recommended by several authors (FAO 1996; Alcalay 1983).

\section{b. Mothers exposure to Campaign materials}

Two brochures and a recipe book were produced for the Campaign, which were used as educational aids. They were sent to 160 mothers of third and fourthgrade children from the schools mentioned above. However, among the 20 mothers studied some materials did not reach their destination. Table 2 summarizes this information.

Although sending materials with school children seems to be a good option to communicate with mothers, when these materials were not delivered, communication was interrupted, thus hindering the 
Cuadro 2. Materiales que las madres recibieron*. Campaña Educativa para incrementar el consumo de frijoles. Sabanilla de Montes de Oca, Costa Rica, 2001.

\begin{tabular}{cc}
\hline Materiales & No. de madres \\
que lo recibieron $* *$
\end{tabular}

Panfleto "Los frijoles son ricos, nutritivos y saludables" 12

Recetario "De todo con frijoles" 12

Panfleto "Los frijoles son

insustituibles"

7

* Solamente 2 madres no recibieron ninguno de los materiales.

** Los datos no son excluyentes.

Aunque el envío de materiales por medio de los escolares pareciera ser una buena opción de comunicación con las madres, esta se vio interrumpida en aquellos casos en que no fueron entregados, lo que limitó el apoyo educativo que podrían haber representado.

En futuras experiencias es importante buscar mecanismos que aseguren la entrega del material y por ende favorezcan los resultados de la intervención. Es posible que un mayor seguimiento por el personal docente contribuya a que los materiales lleguen a su destino.

\section{Efectos de la Campaña sobre los conocimientos relacionados con los frijoles}

Aunque los conocimientos por sí mismos no llevan al cambio de la conducta, si constituyen una base racional importante para el cambio. La Campaña abordó distintos aspectos relacionados con los frijoles, tales como su contenido de nutrientes, las mejores formas de aprovecharlos y el papel de ese alimento en la prevención de enfermedades.

En cuanto al valor nutritivo de los frijoles, la totalidad de las mujeres mencionó al menos uno de los nutrientes que contenían, respuesta que se consideró satisfactoria.

La mitad de las entrevistadas consideró que la mayor cantidad de nutrientes se encontraba en los frijoles (en el grano), no en el caldo, resultado muy positivo ya que en el diagnóstico se había encontrado una acentuada sobrevaloración del contenido nutricional del caldo y un desconocimiento de la importancia de agregar frijoles a la sopa negra, para aumentar su valor nutritivo (Campos et al. 1999).
Table 2. Materials received by mothers*. Educational Campaign to increase bean consumption. Sabanilla de Montes de Oca, Costa Rica, 2001.

\begin{tabular}{|c|c|}
\hline Materials & $\begin{array}{c}\mathrm{N}^{\circ} \text { of mothers } \\
\text { who received them } * *\end{array}$ \\
\hline
\end{tabular}

Brochure "Los frijoles son ricos,

nutritivos y saludables" (Beans

are tasty, nutritious and healthful)

12

Recipe book "De todo con frijoles"

(Everything with beans)

12

Brochure "Los frijoles son insus-

tituibles" (Beans are irreplaceable)

* Only two mothers did not receive any materials at all.

** Data are not mutually exclusive.

educational support those materials may have provided.

In subsequent experiences, it would be important to look for alternative ways to send the materials, in order to ensure their delivery and heighten the intervention's effect. Greater follow-up by teachers will possibly increase the chances of materials reaching their destination.

\section{Effects of the Campaign on knowledge with regards to beans}

Although knowledge by itself does not necessarily entail behavior changes, it does constitute an important rational basis to change. The Campaign addressed different aspects related to beans, such as their nutrient content, the best ways to benefit from them, and the role of this food in disease prevention.

Regarding the nutritional value of beans, all the women gave a satisfactory answer by mentioning at least one of the nutrients they provide.

Half of the women interviewed considered that most of the nutrients are found in bean grains and not in their broth. This is considered a positive result because during the initial assessment it was found that too much emphasis was given to the broth's nutritional content, and that people ignored the importance of adding bean grains to black soup, in order to increase its nutritional value (Campos et al. 1999).

Nine of the women knew that the best way to benefit from iron contained in beans is eating them along with salads. This result was satisfactory: it showed that 
Nueve de las mujeres sabían que el hierro que contienen los frijoles se aprovecha mejor si se consumen con ensalada. Este resultado fue satisfactorio, pues mostró la existencia de un conocimiento que no fue detectado en la etapa diagnóstica (Campos et al. 1999) y que constituyó uno de los aspectos informativos de la Campaña.

La Campaña informó sobre distintas enfermedades que podían ser prevenidas con el consumo de frijoles, enfatizando la anemia, la hipercolesterolemia, la espina bífida, el estreñimiento y la importancia en el tratamiento de la diabetes, la hipertensión arterial y la obesidad. Sin embargo, 15 madres que respondieron a una pregunta sobre este aspecto, se refirieron únicamente a la anemia, lo que ya se había detectado que conocían desde la etapa diagnóstica (Campos et al. 1999). Pareciera que las mujeres tienen mayor interés en las enfermedades que pueden afectarles en el presente y no en el futuro, lo que podría sugerir la necesidad de un replanteamiento de las acciones educativas de prevención.

En términos generales, el grado de conocimientos acertados alrededor de los frijoles resultó satisfactorio, aunque la exposición de las madres a algunas de las actividades y de los materiales de la Campaña, fue parcial.

\section{Efectos de la Campaña sobre las prácticas rela- cionadas con el consumo de frijoles}

\section{a. Frecuencia de consumo de frijoles}

Para el análisis de esta variable, se utilizó como referencia el estudio sobre consumo de frijoles realizado como parte del diagnóstico por Rodríguez y Rodríguez (2003).

Como se observa en el Cuadro 3, la frecuencia de consumo de frijoles varió positivamente en relación con la detectada en la etapa diagnóstica, observándose un incremento significativo en el consumo diario del producto.

El número de veces al día que consumieron frijoles también varió positivamente como se observa en el Cuadro 4. women had acquired a new knowledge, which had not been detected during the initial assessment (Campos et al. 1999), and it was one of the Campaign's teachings.

The Campaign informed about different diseases that might be prevented through bean consumption, emphasizing on anemia, hypercholesterolemia, spina bifida, constipation, as well as on the importance of treating diabetes, high blood pressure, and obesity. However, the 15 mothers who answered a question on this aspect only referred to anemia. Knowledge about this disease in particular had already been detected during the initial assessment (Campos et al. 1999). It seems that women are more concerned with diseases that may affect them in the present, rather than in the future, suggesting that there is a need to redefine preventive educational actions.

In general terms, the degree of correct knowledge about beans was satisfactory, although mothers' exposure to the Campaign's activities and materials was partial.

\section{Effects of the Campaign on practices related to bean consumption}

\section{a. Bean consumption frequency}

The study on bean consumption carried out as part of the initial assessment by Rodríguez and Rodríguez (2003), was used as a reference to analyze this variable.

As may be seen in Table 3, bean consumption frequency increased after the Campaign, and daily consumption was significantly higher than that detected during initial assessment.

The number of times per day that they consumed beans had also a positive change, as shown in Table 4 .

In the study carried out by Rodríguez and Rodríguez (2003), it was found that only one person ate beans for breakfast, while in the present study it was detected that 14 women ate beans at that meal time.

Cuadro 3. Comparación de la frecuencia de consumo de frijoles por las madres. Campaña Educativa para incrementar el consumo de frijoles, Sabanilla de Montes de Oca, Costa Rica, 1999-2001.

\begin{tabular}{|c|c|c|c|c|}
\hline \multirow[t]{2}{*}{ Frecuencia de consumo } & \multicolumn{2}{|c|}{ Antes de la Campaña } & \multicolumn{2}{|c|}{ Después de la Campaña } \\
\hline & Absoluto & Relativo & Absoluto & Relativo \\
\hline Diariamente & 19 & 49 & 17 & 85 \\
\hline Entre 5 y 4 veces por semana & 5 & 13 & 1 & 5 \\
\hline Entre 3 y 2 veces por semana & 14 & 36 & 2 & 10 \\
\hline Una vez por semana & 1 & 2 & - & - \\
\hline Total & 39 & 100 & 20 & 100 \\
\hline
\end{tabular}


Table 3. Comparison of bean consumption frequency by mothers. Educational Campaign to Increase Bean Consumption. Sabanilla de Montes de Oca, Costa Rica, 1999-2001.

\begin{tabular}{lccccr}
\hline \multicolumn{1}{c}{ Consumption frequency } & \multicolumn{2}{c}{ Before the Campaign } & & \multicolumn{2}{c}{ After the Campaign } \\
\cline { 2 - 3 } \cline { 5 - 6 } & Absolute & Relative & & Absolute & Relative \\
\hline Daily & 19 & 49 & & 17 & 85 \\
4 to 5 times per week & 5 & 13 & & 1 & 5 \\
2 to 3 times per week & 14 & 36 & & 2 & 10 \\
Once a week & 1 & 2 & & - & 100 \\
Total & 39 & 100 & & 20 & \\
\hline
\end{tabular}

En el estudio de Rodríguez y Rodríguez (2003), se encontró que solamente una persona comía frijoles al desayuno, mientras que en este estudio fueron detectadas catorce mujeres que dijeron comerlos en ese tiempo de comida. Este resultado podría sugerir que el incremento en la frecuencia diaria de consumo, está dado por un aumento en la frecuencia de consumo de frijoles en el desayuno.

\section{b. Utilización de prácticas recomendadas}

Muchas de las prácticas recomendadas durante la Campaña fueron seguidas por la mayoría de las mujeres entrevistadas.
This result might suggest that the increase in daily consumption is due to an increased frequency of bean consumption for breakfast.

\section{b. Use of recommended practices}

Many of the practices recommended during the Campaign were applied by most of the women interviewed.

Practices related to use of the pressure cooker, soaking beans, and use of natural seasonings to cook them, had already been detected among the women that participated in behavior tests during initial assessment

Cuadro 4. Comparación del número de veces al día que las madres consumieron frijoles. Campaña Educativa para Incrementar el Consumo de Frijoles. Sabanilla de Montes de Oca, Costa Rica, 1999-2001.

\begin{tabular}{lccccc}
\hline \multirow{2}{*}{ Veces al día } & \multicolumn{2}{c}{ Antes de la Campaña } & & \multicolumn{2}{c}{ Después de la Campaña } \\
\cline { 2 - 3 } \cline { 5 - 6 } \cline { 5 - 6 } & Absoluto & Relativo & & Absoluto & Relativo \\
\hline 1 vez por día & 22 & 56 & & 7 & 35 \\
2 veces por día & 17 & 44 & & 11 & 55 \\
3 veces por día & - & - & & 2 & 10 \\
Total & 39 & 100 & & 20 & 100 \\
\hline
\end{tabular}

Table 4. Comparison of number of times per day that women ate beans. Educational Campaign to increase bean consumption. Sabanilla de Montes de Oca, Costa Rica, 1999-2001.

\begin{tabular}{lrrrrr}
\hline \multirow{2}{*}{ Times per day } & \multicolumn{2}{c}{ Before the Campaign } & & \multicolumn{2}{c}{ After the Campaign } \\
\cline { 2 - 3 } \cline { 5 - 6 } & Absolute & Relative & & Absolute & Relative \\
\hline \multirow{2}{1}{ time a day } & 22 & 56 & & 7 & 35 \\
2 times a day & 17 & 44 & & 11 & 55 \\
3 times a day & - & - & & 2 & 10 \\
Total & 39 & 100 & & 20 & 100 \\
\hline
\end{tabular}


Prácticas relacionadas con el uso de la olla de presión, del remojo y de la utilización de condimentos naturales para cocinar los frijoles ya habían sido detectadas en las mujeres que participaron en las pruebas de comportamiento de la etapa diagnóstica (Martínez et al. 2000). En el estudio que nos ocupa, se manifestaron nuevamente esas prácticas.

Otras prácticas, como las de probar nuevas recetas con frijoles, agregar la sal al final de la cocción, remojar los frijoles para mejorar la digestibilidad y congelar los frijoles cocinados en recipientes individuales, probablemente tuvieron su origen en el esfuerzo formativo de la Campaña. Estas prácticas, también fueron seleccionadas para probarlas, por la mayoría de las mujeres que participaron en las pruebas de comportamiento (Martínez et al. 2000, Rodríguez y Murillo 2004b).

En el Cuadro 5 se observan los resultados con respecto a la aplicación de las diferentes prácticas.

Llama la atención que una práctica tan útil como la de congelar los frijoles en porciones familiares para un día, no sea llevada a cabo por más mujeres después de
(Martínez et al. 2000). Those practices were also detected during this study.

Other practices, such as trying out new recipes with beans, adding salt after beans were cooked, soaking beans in water to make them more digestible, and freezing cooked beans in individual containers, were probably learned through the Campaign. In addition, most women participating in behavior tests chose these practices to try them out (Martínez et al. 2000, Rodríguez and Murillo 2004b).

The results with regards to the use of the different recommended practices are shown in Table 5.

It is worth emphasizing that freezing beans in daily family portions - even if it is a very useful practice was not done by more women after the Campaign. These results are different from those found in behavior tests (Rodríguez and Murillo 2004), where a significantly greater number of mothers applied this practice. Perhaps, the household visits and mothers' commitment with the researchers during the behavior tests made it possible to achieve a greater impact than

Cuadro 5. Prácticas recomendadas y número de madres que las aplicaron. Campaña educativa para incrementar el consumo de frijoles. Sabanilla de Montes de Oca, Costa Rica, 2001.

\begin{tabular}{|c|c|}
\hline Prácticas recomendadas & $\begin{array}{l}\text { Número de madres que las aplicaron } \\
\qquad(\mathbf{n = 2 0})^{*}\end{array}$ \\
\hline $\begin{array}{l}\text { Poner los frijoles en olla de presión le permite } \\
\text { cocinar los frijoles en menor tiempo, conservar } \\
\text { su valor nutritivo y ahorrar energía. }\end{array}$ & $\begin{array}{l}15 \text { madres utilizaron la olla mágica para cocinar } \\
\text { los frijoles. }\end{array}$ \\
\hline $\begin{array}{l}\text { Cocinar distintas preparaciones con frijoles. Le } \\
\text { ofrecemos estas prácticas y deliciosas recetas. }\end{array}$ & 11 madres prepararon recetas nuevas con frijoles. \\
\hline $\begin{array}{l}\text { Remojar los frijoles al menos ocho horas antes de } \\
\text { cocinarlos disminuye el tiempo de cocción y hace } \\
\text { que estos alimenten más. } \\
\text { Si los frijoles le caen mal, remójelos al menos o- } \\
\text { cho horas bote el agua de remojo y cocínelos en } \\
\text { suficiente agua nueva. }\end{array}$ & $\begin{array}{l}10 \text { madres remojaron los frijoles, cuatro de ellas } \\
\text { mencionaron que los remojaron porque de esta } \\
\text { manera son más fáciles de digerir o evitar pro- } \\
\text { blemas. }\end{array}$ \\
\hline $\begin{array}{l}\text { Agregar la sal cuando los frijoles ya están cocina- } \\
\text { dos permite que estos se suavicen en menor tiem- } \\
\text { po por lo que hay menos pérdida de nutrientes y } \\
\text { se requiere menor cantidad de sal para obtener la } \\
\text { sazón deseada. }\end{array}$ & $\begin{array}{l}16 \text { madres agregaron la sal cuando ya habían co- } \\
\text { cinado los frijoles. }\end{array}$ \\
\hline $\begin{array}{l}\text { Utilizar solamente condimentos naturales para } \\
\text { cocinar o arreglar los frijoles. }\end{array}$ & $\begin{array}{l}17 \text { madres agregaron condimentos naturales } \\
\text { cuando arreglaron los frijoles. }\end{array}$ \\
\hline $\begin{array}{l}\text { Los frijoles cocinados se conservan mejor y por } \\
\text { más tiempo si se congelan en recipientes con la } \\
\text { cantidad que la familia se come en un día. }\end{array}$ & $\begin{array}{l}\text { dos madres guardaron los frijoles en el congela- } \\
\text { dor luego de cocinarlos. }\end{array}$ \\
\hline
\end{tabular}


Table 5. Recommended practices and number of mother that used them. Educational Campaign to increase bean consumption. Sabanilla de Montes de Oca, Costa Rica, 2001.

\begin{tabular}{l|l}
\hline \multicolumn{1}{c|}{ Recommended practices } & Number of mothers that used them $(\mathbf{n}=\mathbf{2 0})^{*}$ \\
\hline $\begin{array}{l}\text { Use of pressure cooker is time-saving, preserves } \\
\text { beans nutritional value, and saves energy }\end{array}$ & 15 mothers used the pressure cooker to cook beans \\
$\begin{array}{l}\text { Trying out different bean-based preparations. } \\
\text { Practical and tasty recipes are offered. }\end{array}$ & 11 mothers tried out new recipes with beans. \\
$\begin{array}{l}\text { Soaking beans in water at least } 8 \text { hours before } \\
\text { cooking them reduces cooking time and makes } \\
\text { them more nutritious. }\end{array}$ & $\begin{array}{l}10 \text { mothers soaked the beans; } 4 \text { of them said they } \\
\text { soaked beans because it makes them more } \\
\text { digestible or does not upset their stomatch. }\end{array}$ \\
$\begin{array}{l}\text { If beans upset your stomach, soak them for at } 8 \text { hours, throw the soaking water away, and } \\
\text { add new water to cook them. }\end{array}$ & \\
$\begin{array}{l}\text { Adding salt after beans are cooked softens them in } \\
\text { less time, thus less nutrients are lost, and a smaller } \\
\text { amount of salt is required to get the desired taste }\end{array}$ & 16 mothers added salt after beans were cooked. \\
$\begin{array}{l}\text { Using only natural seasonings to cook or prepare } \\
\text { beans. }\end{array}$ & $\begin{array}{l}17 \text { mothers added natural seasonings when } \\
\text { preparing beans. }\end{array}$ \\
$\begin{array}{l}\text { Cooked beans are best preserved and for a longer } \\
\text { time if frozen in containers with the amount that } \\
\text { the family eats in one day. }\end{array}$ & $\begin{array}{l}2 \text { mothers kept beans in the freezer after they were } \\
\text { cooked. }\end{array}$ \\
\hline
\end{tabular}

la Campaña. Estos resultados difieren de lo encontrado en las pruebas de comportamiento (Rodríguez y Murillo 2004), en donde un número considerablemente mayor de madres aplicaron esta práctica. Es posible que el abordaje interactivo (por visita domiciliaria) y el compromiso de las madres con las investigadoras, en las pruebas de comportamiento lograra un mayor impacto que los mensajes que se hicieran llegar por diferentes medios durante la Campaña. Hay que recordar que esta es una práctica poco usual por lo que puede requerir de un abordaje interactivo de mayor duración. Es importante considerar además, que la mayoría de las madres estudiadas trabajan en su casa y es posible que esta práctica sea de mayor utilidad para las mujeres que trabajan fuera de ella.

Los resultados relativos a la aplicación de las prácticas recomendadas coinciden con algunos de los indicadores de éxito planteados para la Campaña y discutidos más adelante.

\section{c. Actitud de las mujeres en relación con los frijoles}

La actitud de las mujeres hacia los frijoles fue valorada mediante la determinación de las razones que ellas tienen para consumirlos. En el Cuadro 6 se presentan estas razones. messages sent through different means during the Campaign. In addition, it is important to keep in mind that since it is an unusual practice, a long-term interactive approach might be required in order to establish this habit. It is also important to consider that many of the women from the sample worked in the house, and perhaps this practice would be more useful for women working outside their homes.

Results regarding use of recommended practices are in agreement with some of the success indicators proposed for the Campaign which are discussed later on.

\section{c. Women's attitude with regards to beans}

Women's attitude with regards to beans was assessed based on their reasons to eat them, which are presented in Table 6.

In conclusion, the mothers' attitude towards beans was generally positive because they acknowledged that beans are nutritious, and that they are part of Costa Rican's eating habits. Nevertheless, it should be pointed out that only 3 said that they ate them because they taste good. 
Cuadro 6. Razones por las que las madres consumieron frijoles. Campaña Educativa para Incrementar el Consumo de Frijoles. Sabanilla de Montes de Oca, Costa Rica, 2001.

\begin{tabular}{lc}
\hline \multicolumn{1}{c}{ Razones } & No. de madres* \\
\hline & 10 \\
Porque son nutritivos & 10 \\
Por costumbre & 3 \\
Porque son ricos & \\
\hline
\end{tabular}

* Los datos no son excluyentes.

Puede deducirse que, en general, la actitud de las madres hacia los frijoles fue positiva, ya que fueron reconocidos como un alimento nutritivo y que forma parte de nuestras costumbres alimentarias, sin embargo, cabe hacer notar que solamente tres expresaron que los consumían porque "son ricos".

\section{d. Cumplimiento de los indicadores de éxito}

Con el fin de evaluar los resultados de la Campaña, en la matriz del plan de comunicación (Martínez et al. 2000; Páez y Rodríguez 2004) se definieron e incluyeron los indicadores de éxito que corresponden a cada uno de los objetivos específicos del plan de Campaña (Rodríguez y Rodríguez 2004.

En el Cuadro 7 se confrontan esos indicadores de éxito con lo encontrado en esta evaluación.

Se puede afirmar que, en general, el efecto de la Campaña en las madres fue positivo, ya que la mayoría de ellas realizaron prácticas, o tenían conocimientos o actitudes que favorecían el consumo de frijoles.

e. Valoración de la campaña educativa por las madres

Con el objetivo de conocer la valoración de las madres acerca de la utilidad de la Campaña, les fue solicitada una calificación de la misma en una escala de 0 a 10. Los resultados obtenidos, se presentan en el Cuadro 8.

Puede observarse que la mayoría de las madres consideró útil la Campaña, asignándole un puntaje de ocho o más.

El tamaño limitado de la submuestra impide llegar a concluir con certeza sobre los cambios que haya producido la Campaña en los conocimientos, las actitudes
Table 6. Reasons for women to eat beans. Educational Campaign to increase bean comsumption. Sabanilla de Montes de Oca, Costa Rica, 2001.

\begin{tabular}{lc}
\hline \multicolumn{1}{c}{ Reasons } & $\mathbf{N}^{\circ}$ of mothers* \\
\hline & 10 \\
Beans are nutritious & 10 \\
Mothers have the habit & 3 \\
Beans are tasty & \\
\hline
\end{tabular}

* Data are not mutually exclusive.

\section{d. Meeting the success indicators}

In order to evaluate the Campaign's results, success indicators were defined and included in the matrix for the communication plan (Martínez et al. 2000, Páez and Rodríguez 2004). These were integrated into the Campaign's plan according to each specific objective (Rodríguez and Rodríguez 2004).

A comparison of success indicators with the findings of this evaluation is presented in Table 7 .

\section{e. Assessment of the educational Campaign by} women

In order to obtain information about women's' appreciation of the Campaign's usefulness, they were requested to grade it in a scale of 0 to 10 . Results obtained are shown in Table 8.

As may be noted, results indicate that most mothers considered the Campaign useful, grading it with 8 or above.

The limited size of the sub-sample did not allow the team to reach definite conclusions about the changes generated by the Campaign on the knowledge, attitudes, and practices of the target population. However, this study shows that the Campaign had a positive effect on the group of mothers studied. The activities implemented and the materials designed might be used to implement the experience elsewhere in the country, even if they could be improved. On the whole, the experience might be repeated in other countries with the corresponding adaptations regarding language, materials, and educational activities. 
Cuadro 7. Indicadores de éxito vs resultados de la evaluación en madres. Campaña educativa para incrementar el consumo de frijoles. Sabanilla de Montes de Oca, Costa Rica, 2001.

\begin{tabular}{|c|c|}
\hline Indicador de éxito & $\begin{array}{l}\text { Número de madres } \\
\qquad(\mathbf{n}=20)\end{array}$ \\
\hline $\begin{array}{l}\text { Que la mayoría reconozca los nutrientes } \\
\text { que contienen los frijoles y los relacionen } \\
\text { con la prevención de enfermedades. }\end{array}$ & $\begin{array}{l}20 \text { madres mencionaron un nutriente } \\
\text { o más de los frijoles. } \\
20 \text { madres relacionan los frijoles con la } \\
\text { prevención de enfermedades. }\end{array}$ \\
\hline $\begin{array}{l}\text { Que la mayoría cocine los frijoles en olla } \\
\text { presión. }\end{array}$ & $\begin{array}{l}15 \text { madres cocinaron los frijoles en olla de } \\
\text { presión. }\end{array}$ \\
\hline Que la mayoría remoje los frijoles. & 10 madres remojaron los frijoles. \\
\hline $\begin{array}{l}\text { Que boten el agua de remojo si los frijoles } \\
\text { les caen mal. }\end{array}$ & $\begin{array}{l}4 \text { madres botaron el agua de remojo porque } \\
\text { los frijoles les provocan molestias*. }\end{array}$ \\
\hline $\begin{array}{l}\text { Que adicionen la sal a los frijoles cuando } \\
\text { están cocinados. }\end{array}$ & $\begin{array}{l}16 \text { madres adicionaron la sal a los frijoles } \\
\text { cuando ya están cocinados. }\end{array}$ \\
\hline $\begin{array}{l}\text { Que la mayoría mantenga una actitud po- } \\
\text { sitiva hacia los frijoles. }\end{array}$ & $\begin{array}{l}19 \text { madres consumieron los frijoles con fre- } \\
\text { cuencia porque consideraron que son ricos } \\
\text { y nutritivos. }\end{array}$ \\
\hline $\begin{array}{l}\text { Que arreglen los frijoles utilizando sola- } \\
\text { mente olores naturales. }\end{array}$ & $\begin{array}{l}16 \text { madres arreglaron los frijoles } \\
\text { con condimentos naturales. }\end{array}$ \\
\hline
\end{tabular}

* Este indicador no puede ser evaluado puesto que no se tiene el dato basal del número de mujeres que presentaron problemas de digestibilidad con tijoles.

Table 7. Success indicators vs results of mothers' final evaluation. Educational Campaign to increase bean consumption. Sabanilla de Montes de Oca, Costa Rica, 2001.

\begin{tabular}{|c|c|}
\hline Success indicator & $\begin{array}{l}\text { Number of mothers } \\
\qquad(\mathbf{n}=\mathbf{2 0})\end{array}$ \\
\hline $\begin{array}{l}\text { Most mothers acknowledge the nutrients } \\
\text { beans provide, and their disease preventing } \\
\text { qualities. }\end{array}$ & $\begin{array}{l}20 \text { mothers could name one or more nutrients } \\
\text { provided by beans. } \\
20 \text { mothers associated beans with disease } \\
\text { prevention. }\end{array}$ \\
\hline $\begin{array}{l}\text { Most mothers cook beans in pressure } \\
\text { cooker. }\end{array}$ & 15 mothers cooked beans in pressure cooker. \\
\hline Most mothers soak beans in water. & 10 mothers soaked beans in water. \\
\hline $\begin{array}{l}\text { Mothers throw soaking water away if beans } \\
\text { upset their stomach. }\end{array}$ & $\begin{array}{l}4 \text { mothers threw the soaking water away } \\
\text { because beans upset their stomach*. }\end{array}$ \\
\hline $\begin{array}{l}\text { Mothers add salt to beans after they are } \\
\text { cooked. }\end{array}$ & $\begin{array}{l}16 \text { mothers added salt to beans after they } \\
\text { were cooked. }\end{array}$ \\
\hline $\begin{array}{l}\text { Most mothers keep a positive attitude with } \\
\text { regards to beans. }\end{array}$ & $\begin{array}{l}19 \text { mothers ate beans frequently because } \\
\text { they think they are tasty and nutritional. }\end{array}$ \\
\hline $\begin{array}{l}\text { Mothers prepare beans using only natural } \\
\text { seasonings. }\end{array}$ & $\begin{array}{l}16 \text { mothers prepared beans using only } \\
\text { natural seasonings. }\end{array}$ \\
\hline
\end{tabular}

* This indicator cannot be assessed because data about the amount of women who presented digestion problems is not available. 
Cuadro 8. Valoración de la utilidad de la Campaña por parte de las madres. Campaña Educativa para Incrementar el Consumo de Frijoles. Sabanilla de Montes de Oca, Costa Rica, 2001

\begin{tabular}{cc}
\hline Puntaje* $^{*}$ & No. de madres \\
\hline 10 & 4 \\
9 & 4 \\
8 & 9 \\
7 & 1 \\
6 & 2 \\
Total & 20 \\
\hline
\end{tabular}

* Escala de 0 a 10.

y las prácticas de la población objetivo. Sin embargo, este estudio refleja efectos positivos y satisfactorios de la Campaña en las madres evaluadas. Las actividades implementadas y los materiales desarrollados, si bien es cierto pueden ser mejorados, sirven de base para utilizarlos en otras zonas del país. La experiencia también podría ser replicada en otros países, con la debida adaptación del lenguaje, de los materiales y de las actividades educativas.

\section{LITERATURA CITADA}

ALCALAY, R. 1983. The impact of mass communication campaigns in the health field. Social scientists medicine 17(2): 87-94.

CAMPOS, E.; FERNÁNDEZ, A.; SÁNCHEZ I.; SANCHO, T.; VILLALOBOS, C. 1999. Diagnóstico para una Campaña educativa para aumentar el consumo de frijol. Seminario de Licenciatura. San José, Costa Rica: Universidad de Costa Rica. 153 p.

DE LA RIVA, G. 1998. ¿Por qué come lo que come la población de Mérida? In: Cuadernos de Nutrición 21(5): 3646.

DUMANI, M.; LÓPEZ, E. 2004. Monitoreo de los materiales escritos y de los puestos de información de una Campaña educativa para aumentar el consumo de frijoles. Agronomía Mesoamericana 15(3): 343-355.

FAO. 1996. Guía metodológica de comunicación social en nutrición. Roma, Italia: FAO. p. 101.

FERNÁNDEZ, K.; JIMÉNEZ, K.; VARGAS, G. 2000. Modificaciones para mejorar la alimentación, identificadas mediante una metodología participativa en once familias urbano-marginales de San José. Seminario de Licenciatura. San José, Costa Rica: Universidad de Costa Rica. 129 p.
Table 8. Assessment of Campaign's usefulness by mothers. Educational Campaign to increase bean consumption. Sabanilla de Montes de Oca, Costa Rica, 2001

\begin{tabular}{cc}
\hline Year level* $^{*}$ & $\mathbf{N}^{\circ}$ of mothers \\
\hline 10 & 4 \\
9 & 4 \\
8 & 9 \\
7 & 1 \\
6 & 2 \\
Total & 20 \\
\hline
\end{tabular}

* Scale of 0 to 10 .

\section{REFERENCES}

ALCALAY, R. 1983. The impact of mass communication campaigns in the health field. Social scientists medicine 17(2): 87-94.

CAMPOS, E.; FERNÁNDEZ, A.; SÁNCHEZ I.; SANCHO, T.; VILLALOBOS, C. 1999. Diagnóstico para una Campaña educativa para aumentar el consumo de frijol. Seminario de Licenciatura. San José, Costa Rica: Universidad de Costa Rica. 153 p.

DE LA RIVA, G. 1998. ¿Por qué come lo que come la población de Mérida? In: Cuadernos de Nutrición 21(5): 3646.

DUMANI, M.; LÓPEZ, E. 2004. Monitoreo de los materiales escritos y de los puestos de información de una Campaña educativa para aumentar el consumo de frijoles. Agronomía Mesoamericana 15(3): 343-355.

FAO. 1996. Guía metodológica de comunicación social en nutrición. Roma, Italia: FAO. p. 101.

FERNÁNDEZ, K.; JIMÉNEZ, K.; VARGAS, G. 2000. Modificaciones para mejorar la alimentación, identificadas mediante una metodología participativa en once familias urbano-marginales de San José. Seminario de Licenciatura. San José, Costa Rica: Universidad de Costa Rica. 129 p.

ENCUESTA DE NUTRICIÓN DE CANARIAS (ENCA). 1997-1998, 5-1 (en línea). Islas Canarias, España. Consultado el 15 de noviembre de 2002. Disponible en: www.gobcan.es/psc/enca/tomo5/primera1.htm\#11

INCAP/ICNND/ MINISTERIO DE SALUBRIDAD PÚBLICA DE COSTA RICA. 1969. Evaluación nutricional de la población de Centroamérica y Panamá: Costa Rica. Publicación INCAP-V-28. Guatemala, Guatemala: INCAP. 113 p. 
ENCUESTA DE NUTRICIÓN DE CANARIAS (ENCA). 1997-1998, 5-1 (en línea). Islas Canarias, España. Consultado el 15 de noviembre de 2002. Disponible en: www.gobcan.es/psc/enca/tomo5/primera1.htm\#11

INCAP/ICNND/ MINISTERIO DE SALUBRIDAD PÚBLICA DE COSTA RICA. 1969. Evaluación nutricional de la población de Centroamérica y Panamá: Costa Rica. Publicación INCAP-V-28. Guatemala, Guatemala: INCAP. 113 p.

MARTÍNEZ, T.; MURILLO, A; PÁEZ, P.; RODRÍGUEZ, S. 2000. Elaboración de los contenidos de los mensajes de una Campaña Educativa para aumentar el consumo de frijol en una comunidad del área urbana de clase media. Seminario de Licenciatura. San José, Costa Rica: Universidad de Costa Rica. 103 p.

MINISTERIO DE SALUD. 1986. Encuesta Nacional de Nutrición: Evaluación Dietética 1982. San José, Costa Rica: Ministerio de Salud. 63 p.

1996. Encuesta Nacional de Nutrición. Fascículo 3: Consumo Aparente. San José, Costa Rica. p. 45.

; Dirección General de Estadísticas y Censos. 1991. I Encuesta Nacional sobre Consumo Aparente de Alimentos, 1989. Costa Rica: Programa de Seguridad Alimentaria del Istmo Centroamericano, CADESCACEE. San José, Costa Rica: Ministerio de Salud. p. 33.

MURILLO, A.; RODRÍGUEZ, S. 2004. Conocimientos, actitudes y prácticas de madres de escolares con respecto a los frijoles. Agronomía Mesoamericana 15(3): 277-289.

PAEZ, L.; RODRÍGUEZ, L. Plan de comunicación: una buena herramienta para que su Campaña tenga éxito. Agronomía Mesoamericana 15(3): 315-326.

RODRÍGUEZ, S; MURILLO, A. 2004. Frijoles: prácticas factibles para madres de escolares. Escuela de Nutrición, Universidad de Costa Rica. San José, Costa Rica. Agronomía Mesoamericana 15(3): 301-313.

RODRÍGUEZ, L; PÁEZ, P. 2004. Incremento del consumo de frijoles en una población urbana por medio de una Campaña educativa. San José, Costa Rica. Agronomía Mesoamericana 15(3):357-363.

; RODRÍGUEZ, S. 2003. Consumo de frijoles y atención en salud de familias de una comunidad urbana de Costa Rica. Revista Costarricense de Salud Pública, 12(23): 47-51.

; RODRÍGUEZ, S. 2004. Proceso metodológico para la planificación y ejecución de una Campaña educativa para incrementar el consumo de frijoles. Agronomía Mesoamericana 15(3): 327-341.

; FERNÁNDEZ, X. 2003. Los frijoles (Phaseolus vulgaris): Su aporte a la dieta del costarricense. Acta Médica Costarricense 45(3): 120-125.
MARTÍNEZ, T.; MURILLO, A; PÁEZ, P.; RODRÍGUEZ, S 2000. Elaboración de los contenidos de los mensajes de una Campaña Educativa para aumentar el consumo de frijol en una comunidad del área urbana de clase media. Seminario de Licenciatura. San José, Costa Rica: Universidad de Costa Rica. 103 p.

MINISTERIO DE SALUD. 1986. Encuesta Nacional de Nutrición: Evaluación Dietética 1982. San José, Costa Rica: Ministerio de Salud. 63 p.

1996. Encuesta Nacional de Nutrición. Fascículo 3: Consumo Aparente. San José, Costa Rica. p. 45.

; Dirección General de Estadísticas y Censos. 1991. I Encuesta Nacional sobre Consumo Aparente de Alimentos, 1989. Costa Rica: Programa de Seguridad Alimentaria del Istmo Centroamericano, CADESCACEE. San José, Costa Rica: Ministerio de Salud. p. 33.

MURILLO, A.; RODRÍGUEZ, S. 2004. Conocimientos, actitudes y prácticas de madres de escolares con respecto a los frijoles. Agronomía Mesoamericana 15(3): 277-289.

PAEZ, L.; RODRÍGUEZ, L. Plan de comunicación: una buena herramienta para que su Campaña tenga éxito. Agronomía Mesoamericana 15(3): 315-326.

RODRÍGUEZ, S; MURILLO, A. 2004. Frijoles: prácticas factibles para madres de escolares. Escuela de Nutrición, Universidad de Costa Rica. San José, Costa Rica. Agronomía Mesoamericana 15(3): 301-313.

RODRÍGUEZ, L; PÁEZ, P. 2004. Incremento del consumo de frijoles en una población urbana por medio de una Campaña educativa. San José, Costa Rica. Agronomía Mesoamericana 15(3):357-363.

; RODRÍGUEZ, S. 2003. Consumo de frijoles y atención en salud de familias de una comunidad urbana de Costa Rica. Revista Costarricense de Salud Pública, 12(23): 47-51.

; RODRÍGUEZ, S. 2004. Proceso metodológico para la planificación y ejecución de una Campaña educativa para incrementar el consumo de frijoles. Agronomía Mesoamericana 15(3): 327-341.

; FERNÁNDEZ, X. 2003. Los frijoles (Phaseolus vulgaris): Su aporte a la dieta del costarricense. Acta Médica Costarricense 45(3): 120-125. 